\title{
Punching Shear Behavior of Interior Slab-Column Connections Reinforced with Vertical Bolts
}

\author{
Fatma A. Ebrahim $^{\text {a,b }}$, Hamed S. Askar, Ph.D. ${ }^{\text {c }, \text { El-Zoughiby M. El-Said, Ph.D. }}{ }^{\text {d }}$ \\ Mohamed H. Mathana, Ph.D.
}

${ }^{a}$ Master student, Structural Engineering Department, Faculty of Engineering, Mansoura University, Egypt, ${ }^{+}$Corresponding Author, Cell Phone: (+2) 01060274435, E-mail:

eng.battota@yahoo.com.

${ }^{\mathrm{b}}$ Demonstrator at High institute of Engineering and Technology in New Damietta, Egypt.

c professor, Structural Engineering Department, Faculty of Engineering, Mansoura University, Mansoura 35516, Egypt, Cell phone: (+2) 01223154088, E-mail: Hamedsaskar@yahoo.com.

${ }^{\mathrm{d}}$ Associate Professor, Structural Engineering Department, Faculty of Engineering, Mansoura University, Mansoura 35516, Egypt, Cell phone: (+2) 01142966288, E-mail:

melzoughiby@yahoo.com.

${ }^{\mathrm{e}}$ Associate Professor, Structural Engineering Department, Faculty of Engineering, Mansoura University, Mansoura 35516, Egypt, Cell phone: (+2) 01060005339, E-mail:

Mhmatthana@hotmail.com.

\begin{abstract}
Punching shear failure in flat plate slabs is considered as a vital topic to investigate. The fact that this failure is brittle makes it an essential field to study. Many researches have been carried out to investigate the punching shear of flat plate slabs. Nevertheless, using prestressing in enhancing punching behavior wasn't of such a big contribution. An experimental study for enhancing punching shear volume of interior slab-column links in flat plate slabs by prestressing is presented through a parametric study in this research. The parameters taken into consideration in this study are prestressed vertical studs of different number of rows. Through the experimental program, deformation features, the load carrying capacity, and the cracking patterns have
\end{abstract}


been examined. A comparative study between the behavior of the improved slabs and their controls has been made. This study showed that the suggested system might be of a good benefit in practice to be used. A comparison between the experimental punching load and the calculated using various design codes has also been made. It offered acceptable agreement.

\section{Keywords}

Enhancement; Reinforced concrete; prestressing bolts; punching shear capacity; shear reinforcement

\section{Notations}

$\boldsymbol{b}_{\boldsymbol{o}} \quad$ control shear perimeter assumed to be at $0.5 \mathrm{~d}$ from the column perimeter

$\alpha$ equal 4.0 for interior columns

$\boldsymbol{d}$ the effective depth of the slab

$f_{y} \quad$ yield strength of the shear reinforcement

$\boldsymbol{a}, \boldsymbol{b}$ smaller and longer column dimensions

$\boldsymbol{q}_{\text {cup }}$ concrete shear strength

$f_{c u} \quad$ strength of standard cube 150 $\mathrm{mm}$

$\gamma_{\mathrm{c}}$ factor of safety for concrete equal 1.5

$\boldsymbol{q}_{u p}$ slab shear strength with shear reinforcement

$\boldsymbol{q}_{\text {sup }} \quad$ stirrups shear strength
$\mathbf{A}_{\text {st }}$ cross sectional area of the used stirrups along the control shear perimeter

S distance between two adjacent stirrups in one direction

$\boldsymbol{d}_{\boldsymbol{s}} \quad$ diameter of the prestressed studs

$\boldsymbol{d}_{\boldsymbol{s}, \text { act }}$ actual diameter of the prestressed studs after removing the thread

$\boldsymbol{S}_{\boldsymbol{n}} \quad$ number of prestressed studs in a specimen

$\rho_{s} \quad$ punching shear reinforcement ratio

$\boldsymbol{P F}$ prestressing force in studs

$\boldsymbol{d}_{\text {eff }}$ effective depth of tested slabs

$\boldsymbol{n}_{\boldsymbol{r}} \quad$ number of radii of shear reinforcement

NSC normal strength concrete 


\section{Introduction}

The use of external shear reinforcement is one of the most common strengthening techniques. Addition of studs has been examined experimentally by Heinzmann et al [1]. The results of an extensive experimental campaign on 16 flat plate-slab specimens with and without punching shear reinforcement were investigated and compared to design codes by Lips et al. [2]. Strengthening of existing flat plate-slabs using post-installed studs as shear reinforcement has been experimentally tested and observed by Muttoni et al. [3]. Results indicated that such reinforcement is efficient to raise both the strength and deformation ability of flat plate- slabs. Strengthening of concrete slab-column connections using CFRP strips has been tested by Soudki et al [4, $5,6]$. The test results clearly showed that CFRP strips significantly improve the structural behavior of slab-column connections. The influence of mid-thickness rebar mesh on the behavior and punching shear power of the inside of the slabcolumn links has been investigated by Ibrahim et al [7]. The influence of column size and slab slenderness on punching strength has been also investigated by Einpaul et al. [8]. Ghali et al. [9] improved the slabs punching shear strength by adding prestressed bolts. Duarte et al. [10] stated experimental results of four slabs enhanced by means of transversal prestressed bolts with various features and experienced under punching. Mostafaei et al. [11] examined the punching behavior of externally prestressed concrete slabs. The effect of joining fiber enriched polymer sheets (FRP) on the rehabilitation of punching shear features has been tested by Abdullah et al. [12]. Asker [13] proved the ability of the prestressing mechanism in repairing damaged flat plates as a result of punching. The suggested system referred to an important improvement in the behavior of the fixed slabs.

\section{Codes provisions}

This current section summarizes the differences between the various design codes in calculating punching shear capacity. The considered codes in this investigation are the ACI 318-11 [14], the Eurpcode-2-EC2 [15], the Canadian Standard CSA A23.3-04 [16], the New Zealand Standard NZS 3101 (2006) [17], and the Egyptian Code of Practice ECP 203-2018 [18]. These codes adopted equations for estimating punching shear capacities for slabs with or without shear reinforcement. The major differences among these codes include the position of the critical shear perimeter, the contribution of flexural reinforcement ratio, and the account for slab size. For critical shear perimeter, it is taken at $\frac{d}{2}$ of the border of the support region based on ACI 318-11 [14] requirements and at $2 \mathrm{~d}$ according Eu-2 [15]. The CSA A23.3-04 [16], NZS 3101 (2006) [17], and ECP 203-2018 are similar to the ACI by taking the critical shear perimeter at $\frac{d}{2}$ from the loaded area. For contribution of the flexural reinforcement ratio, only Eu-2 takes it into consideration. For slab size 
effect, only Eu-2 and NZS 3101 (2006) consider a factor $k$ to lessen the final punching shear strength of slabs thicker than $200 \mathrm{~mm}$. The equations used by the Egyptian Code of Practice: ECP 203-2018 [18] are detailed as:

a) Without shear reinforcement:

$\mathrm{q}_{\text {cup }}$ (uncracked) is the smallest of the following:

$$
\begin{array}{ll}
\mathrm{q}_{\text {cup }}(\text { uncracked })=0.8\left[\left(\alpha \mathrm{d} / \mathrm{b}_{\mathrm{o}}\right)+0.2\right] \sqrt{\frac{f_{c u}}{\gamma c}} & \frac{\mathrm{N}}{\mathrm{mm}^{2}} \\
\mathrm{q}_{\text {cup }}(\text { uncracked })=0.316[0.5+(\mathrm{a} / \mathrm{b})] \sqrt{\frac{f_{c u}}{\gamma c}} & \frac{\mathrm{N}}{\mathrm{mm}^{2}} \\
\mathrm{q}_{\text {cup }}(\text { uncracked }) \leq 0.316 \sqrt{\frac{f_{c u}}{\gamma c}} & \frac{\mathrm{N}}{\mathrm{mm}^{2}} \\
\mathrm{q}_{\text {cup }} \leq 1.7 \frac{\mathrm{N}}{\mathrm{mm}^{2}} &
\end{array}
$$

b) With (stirrups) as shear reinforcement: (for slabs with thickness more than $250 \mathrm{~mm}$ ):

$$
\begin{aligned}
& \mathrm{q}_{\mathrm{up}}(\text { cracked })=0.12 \sqrt{\frac{f_{c u}}{\gamma c}}+\mathrm{q}_{\text {sup }} \leq \mathrm{q}_{\mathrm{u}-\max } \\
& \text { Where: } \quad \mathrm{q}_{\text {sup }}=\frac{\mathrm{A}_{\text {st. } \mathrm{f}_{\mathrm{y}}}}{\mathrm{s} \cdot b_{0} \gamma_{c}}, \mathrm{f}_{\mathrm{y}} \leq 350 \frac{\mathrm{N}}{\mathrm{mm}^{2}} \\
& \mathrm{q}_{\mathrm{u}-\max } \leq 0.45 \sqrt{\frac{f_{c u}}{\gamma c}}
\end{aligned}
$$

\section{Research objective}

The essential objective of the conducted experimental program is to study the effect of prestressing using vertical prestressed bolts in enhancing the ultimate punching shear capacity of interior slab-column links. The results of each specimen have been compared with the reference specimen. The comparative study indicated that the enhanced slabs acquired higher cracking load, higher punching failure capacity and less deformability related to their reference slabs. Through this research, the shear reinforcement ratio is the main parameter of investigation.

\section{Experimental program}

An experimental program that includes four square flat plate specimens, was performed. All specimens were formed of normal strength concrete and had a variable punching shear reinforcement ratio. The details of test specimens are shown in Figs. 1, 2, and 3 and Table 1. 

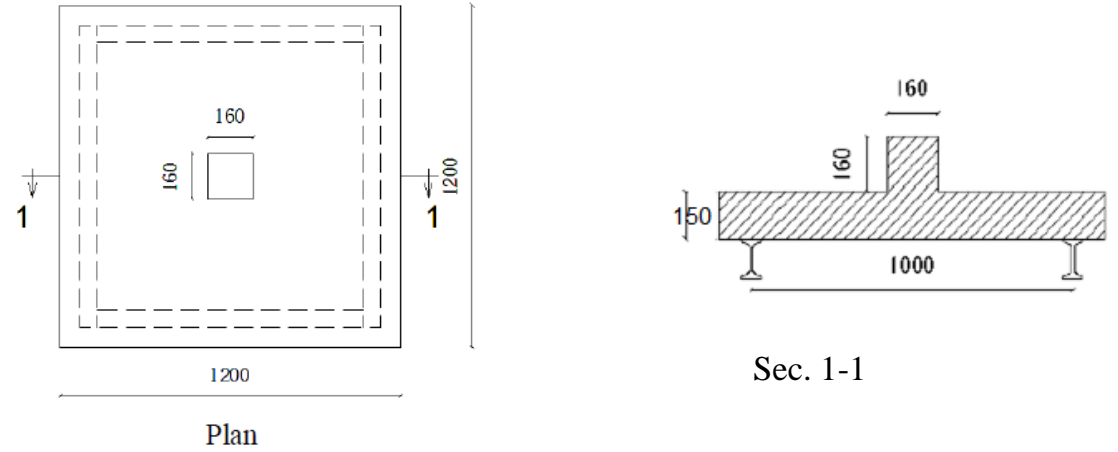

Sec. 1-1

Figure 1 Typical specimen geometry, dimensions in (mm)
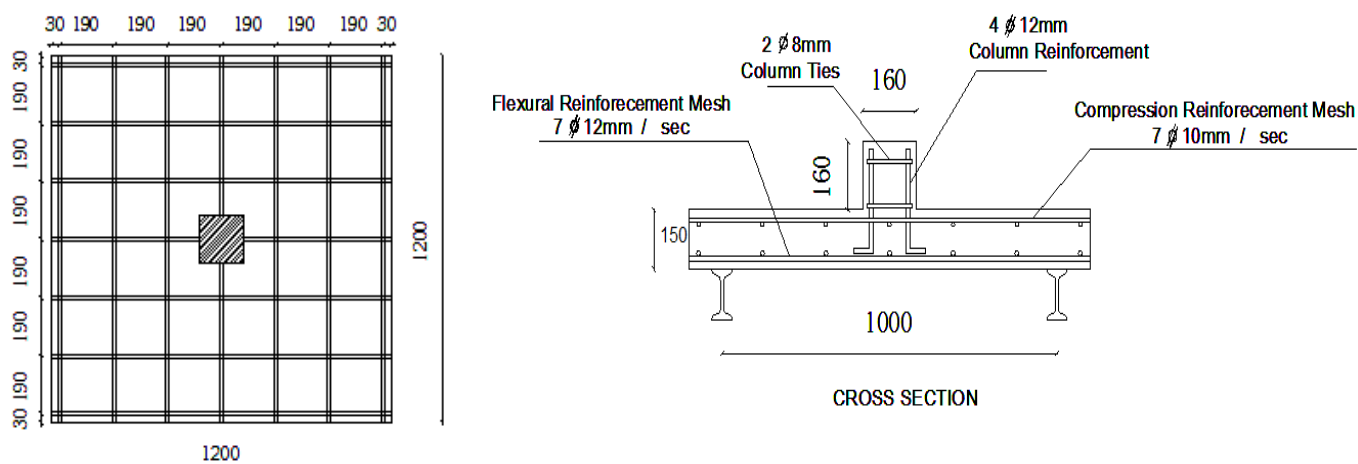

Figure 2 Typical reinforcement steel arrangement details, dimensions in (mm)
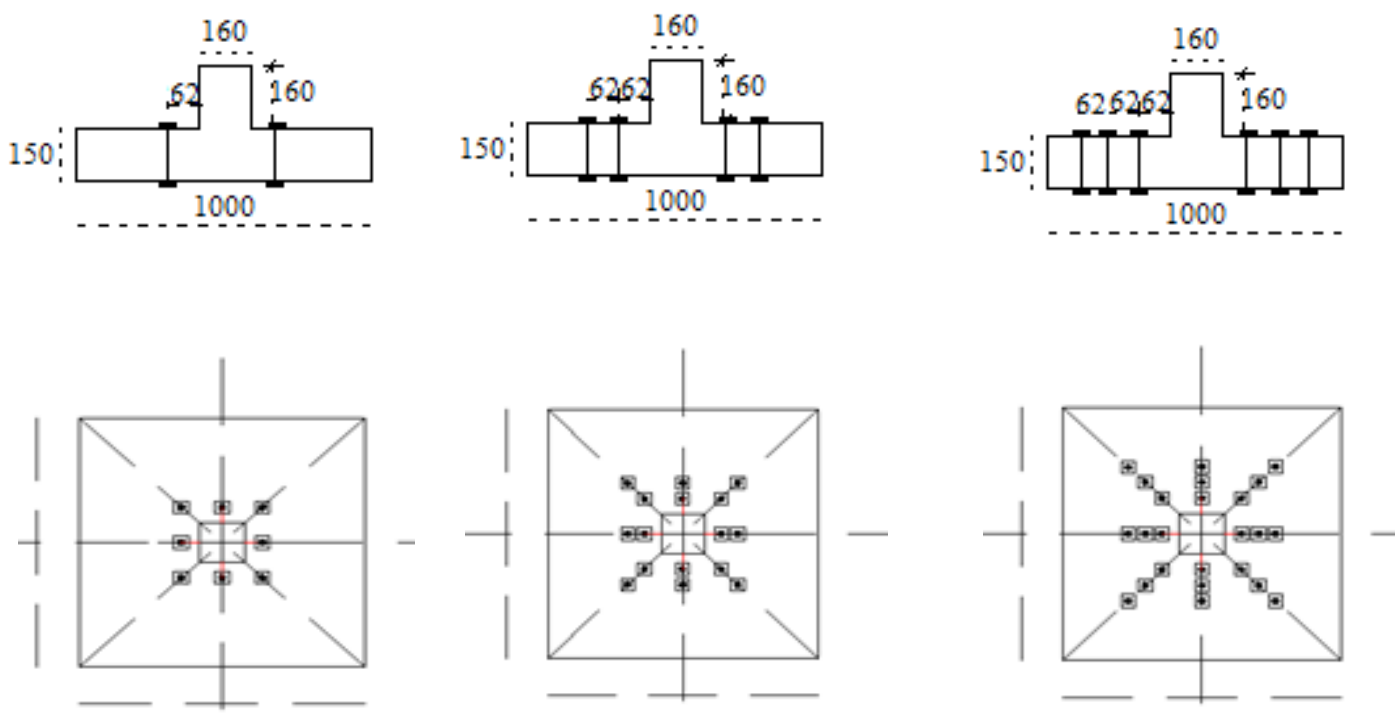

Figure 3 Typical prestressed bolts layout details of slabs A1-8, A2-16, A3-24, dimensions in $(\mathrm{mm})$ 
Table 1 Details of the tested specimens

\begin{tabular}{llllllll}
\hline $\begin{array}{l}\text { Specime } \\
\mathbf{n}\end{array}$ & $\boldsymbol{f}_{\text {cu }}(\mathbf{M P a})$ & $\mathbf{d}_{\mathbf{s}}(\mathbf{m m})$ & $\mathbf{d}_{\mathrm{s}, \mathrm{act}}$ & $\mathbf{S}_{\mathbf{n}}$ & $\boldsymbol{\rho}_{\mathbf{s} \%}$ & $\boldsymbol{P F}(\mathbf{k N})$ & $\mathbf{d}_{\text {eff }}$ \\
\hline $\mathbf{A}_{\mathbf{0}} \mathbf{- 0}$ & 39 & $\ldots$ & $\ldots$ & $\ldots$ & $\ldots$ & $\ldots$ & 124 \\
$\mathbf{A 1 - 8}$ & 41 & 12 & 10 & 8 & .892 & 8 & 124 \\
$\mathbf{A 2 - 1 6}$ & 39 & 12 & 10 & 16 & 1.78 & 8 & 124 \\
$\mathbf{A 3 - 2 4}$ & 38 & 12 & 10 & 24 & 2.68 & 8 & 124 \\
\hline
\end{tabular}

A1-8: 1 refers to specimen number and 8 refers to number of bolts

\section{Specimens}

The tested specimens as presented in Table 1 and Figs. 1, 2, and 3 are square flat plates $1200 \mathrm{~mm}$ length and $150 \mathrm{~mm}$ thick with $160 \mathrm{~mm}$ square reinforced concrete column stubs extending $160 \mathrm{~mm}$ above the plate. The column stub was cast monolithically with the slab. All of the tested slabs were similar in dimensions. In this study, the punching shear reinforcement ratio as shown in Table 1 is the only considered parameter which affects the punching shear capacity and strain energy of the tested specimens. For the flexural reinforcement ratio, all specimens had a constant ratio of $0.532 \%$ (7申12/section). The ratio of shear reinforcement in this investigation $\left(\rho_{s}\right)$ is calculated for studied specimens from the following relation: $\rho_{s}=\mathrm{n}_{\mathrm{r}} \cdot \pi / 4 \cdot \mathrm{d}_{\mathrm{s}}{ }^{2} /$ $\left[4 \mathrm{~S}_{\mathrm{e}}(\mathrm{C}+\mathrm{d})\right]$, built upon the formula mentioned by Lips et al. [2] at perimeter at $\mathrm{d} / 2$ of the edge of the support region: $\rho_{s}=\mathrm{n}_{\mathrm{r}} \cdot \pi / 4 \cdot \mathrm{d}_{\mathrm{s}}{ }^{2} /\left[\mathrm{S}_{\mathrm{e}}(4 \mathrm{c}+\pi \mathrm{d}]\right.$, to take into account that rows of shear studs are put at a rectangular form not a circular form. where $n_{r}$ represents the number of radii of shear reinforcement, $d_{s}$ represents the bolt diameter, $S_{\mathrm{e}}$ represents the distance between two neighbouring reinforcements in the radial direction, c represents the column side length and d represents the slab's effective depth.

\section{Materials}

The properties of all used steel in the tested specimens are shown in Table 2. NSC was employed in all tested specimens with target strength $\mathrm{f}_{\mathrm{cu}}$ of $40 \mathrm{MPa}$. The results of the compressive strength test $(150 \mathrm{~mm}$ cubes) are presented in Table 3. Table 4 shows the used proportions of concrete mix. As shown in Fig. 4, specimens were batched on different occasions. 
Table 2 Properties of all used steel in the tested specimens

\begin{tabular}{|l|l|l|}
\hline Type & $\boldsymbol{F y}(\mathrm{MPa})$ & $\boldsymbol{F u}(\mathrm{MPa})$ \\
\hline Mild steel (ties) & 247 & 356 \\
\hline $\begin{array}{l}\text { High grade (Rft } \\
\text { steel) }\end{array}$ & 451 & 619 \\
\hline High grade (bolts) & 425 & 535 \\
\hline
\end{tabular}

Table 3 Compressive strength test results $(150 \mathrm{~mm}$ cubes)

\begin{tabular}{|c|c|c|c|c|}
\hline Specimen & $\begin{array}{l}f_{\text {cu-7days }} \\
(\mathbf{M P a})\end{array}$ & $\begin{array}{c}\text { Average } \\
\text { (MPa) }\end{array}$ & $\begin{array}{c}f_{\text {cu-28days }} \\
\text { (MPa) }\end{array}$ & $\begin{array}{c}\text { Average } \\
\text { (MPa) }\end{array}$ \\
\hline Ао-0 & $\begin{array}{l}28.4 \\
22.2 \\
29.3\end{array}$ & 26.6 & $\begin{array}{l}40.2 \\
38.7 \\
38.1\end{array}$ & 39 \\
\hline A1-8 & $\begin{array}{l}32.4 \\
25.1 \\
29.5\end{array}$ & 29 & $\begin{array}{l}42.7 \\
38.5 \\
41.8\end{array}$ & 41 \\
\hline A2-16 & $\begin{array}{c}25 \\
30.2 \\
25.3\end{array}$ & 26.8 & $\begin{array}{c}38.7 \\
41.3 \\
37\end{array}$ & 39 \\
\hline A3-24 & $\begin{array}{l}25.8 \\
26.4 \\
22.8\end{array}$ & 25 & $\begin{array}{l}39.8 \\
37.4 \\
36.8\end{array}$ & 38 \\
\hline
\end{tabular}

Table 4 Concrete mix quantities for NSC

\begin{tabular}{|lcc|}
\hline \multicolumn{3}{|c|}{ Used material } \\
\hline & Mix proportions & $\begin{array}{c}\text { Dry weight } \\
\left(\mathrm{kg} / \mathrm{m}^{3}\right)\end{array}$ \\
\hline Standard Portland cement & 1.00 & 500 \\
Fine aggregate (sand) & 1.19 & 595 \\
Dolomite (10 mm) & 2.21 & 1105 \\
Water & 0.43 & 215 \\
\hline
\end{tabular}



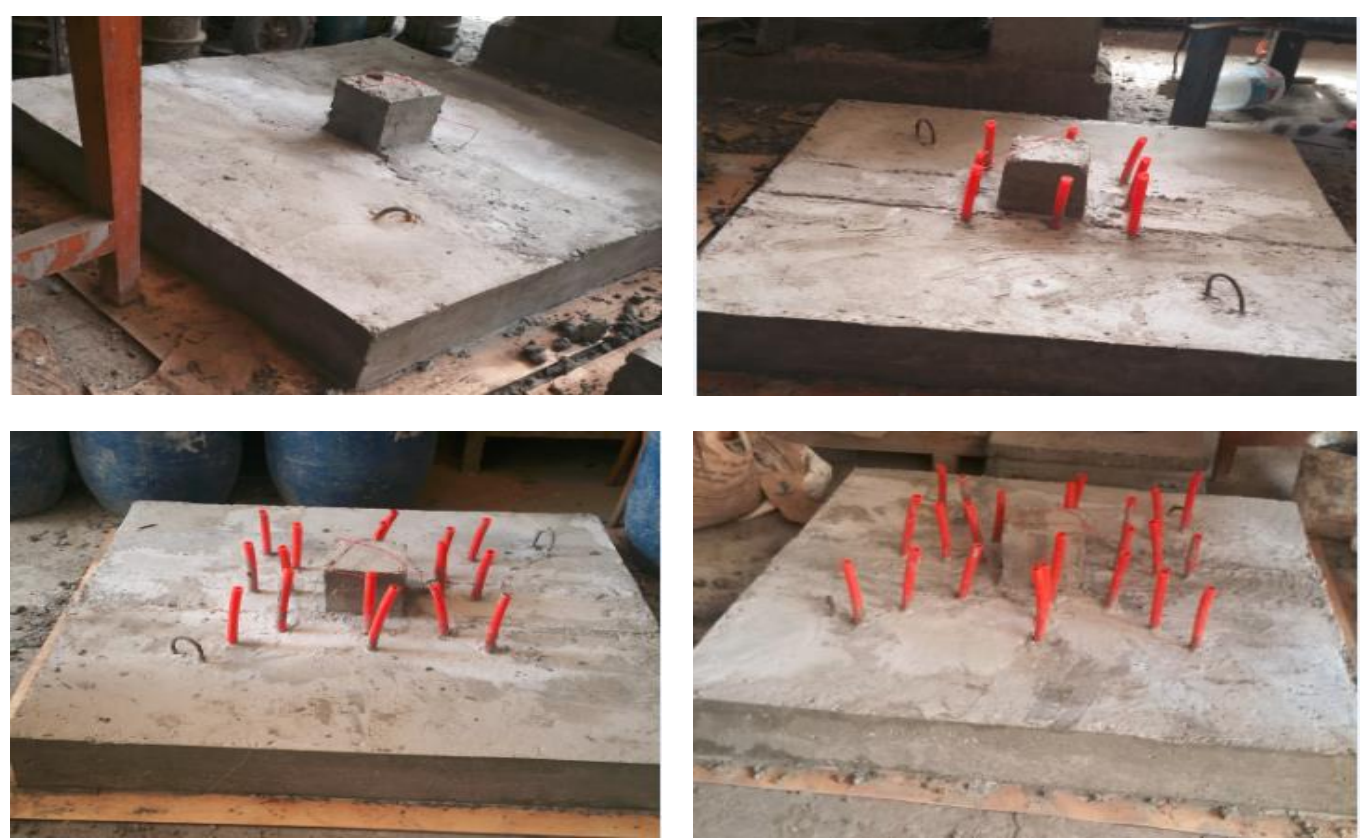

Figure 4 Casting procedures

\section{Test Instrumentation}

Monitoring the vertical displacement at the center of the specimens has been made by means of linear variable differential transformer (LVDT). Linear electrical strain gauges were used to record the measured strains measured in studs and flexural reinforcement bars. All bolts were machined for a length of about $15 \mathrm{~mm}$ in order to eliminate the thread and get a smooth surface. Then, strain gauges were pasted. The actual stud measured diameter is $10 \mathrm{~mm}$ after being machined. The gauges were separated against the leakage of liquids using glue. These steps were used also for the flexural bars. The arrangement of linear strain gauges in all tested slabs is shown in Fig. 5. Finally, at testing, the strain gauges were connected to a strain indicator and recorder.
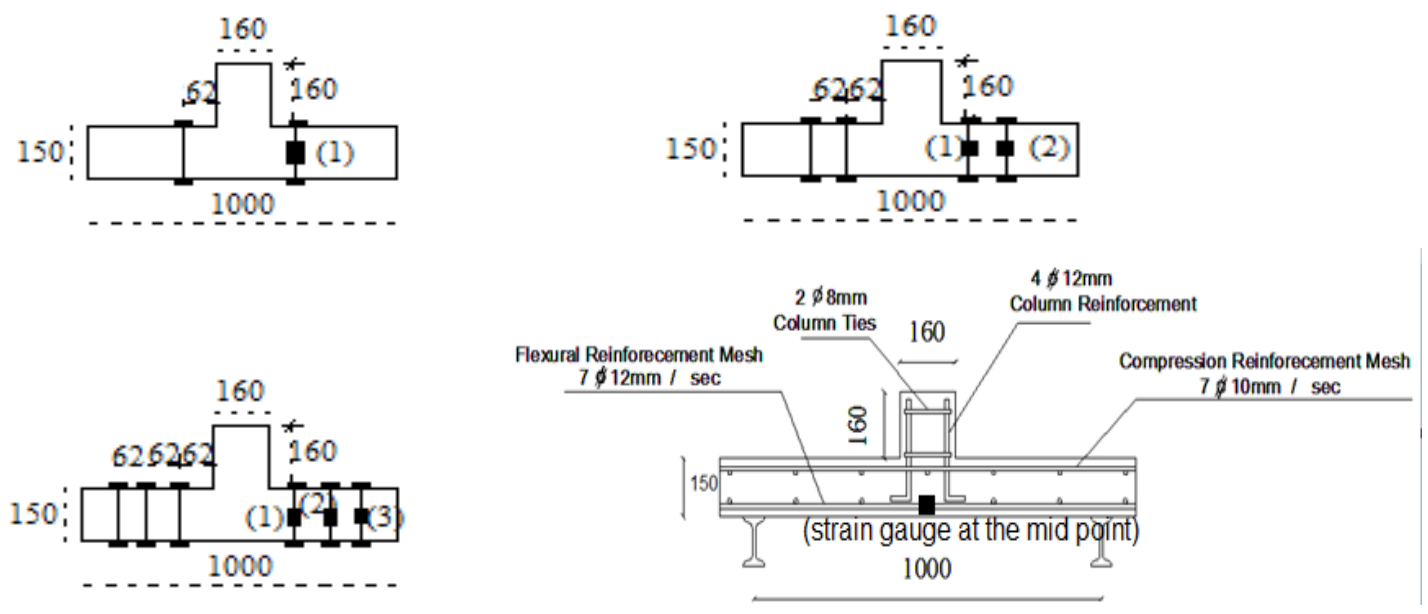

Figure 5 Location of strain guages in tested slabs 


\section{Bolts and prestressing}

The locations of bolts were carefully marked on the formwork before casting according to their design. For marking the locations of bolts, 48 hoses were used during concrete casting. Eight hoses were used for specimen A1-8, 16 for specimen A2-16 and 24 for specimen A3-24. The diameter of hoses was 14 $\mathrm{mm}$ inside and $16 \mathrm{~mm}$ outside. After setting of the concrete, the hoses were removed letting holes in slabs. The proposed prestressing force for each bolt was $8 \mathrm{kN}$. For applying the required prestressing force, a calibrated torque spanner was used. The calibration was carried-out using universal testing machine of tension. The bolt's bar was installed in the machine and by means of the torque spanner; the bolt nut was tightened continuously so that the gauge of the machine recorded $8 \mathrm{kN}$. At this situation, the scaled hand was locked at this reading until it got ready for applying the required prestressing tensile force of $8 \mathrm{kN}$ per bolt. After removing the hoses, the holes were cleaned from dust, then filled with bonding epoxy paste for repairing the bolts with the concrete. Each bolt has two steel plates at its ends of dimensions $50 * 50 * 5 \mathrm{~mm}$ as washers and nuts were setting through the bonding epoxy paste from the bottom side to the top surface of slab. Next, the calibrated torque spanner was used to stiffen the top washer and nut of each bolt till reaching the design prestressing tensile force, as shown in Fig. 6.
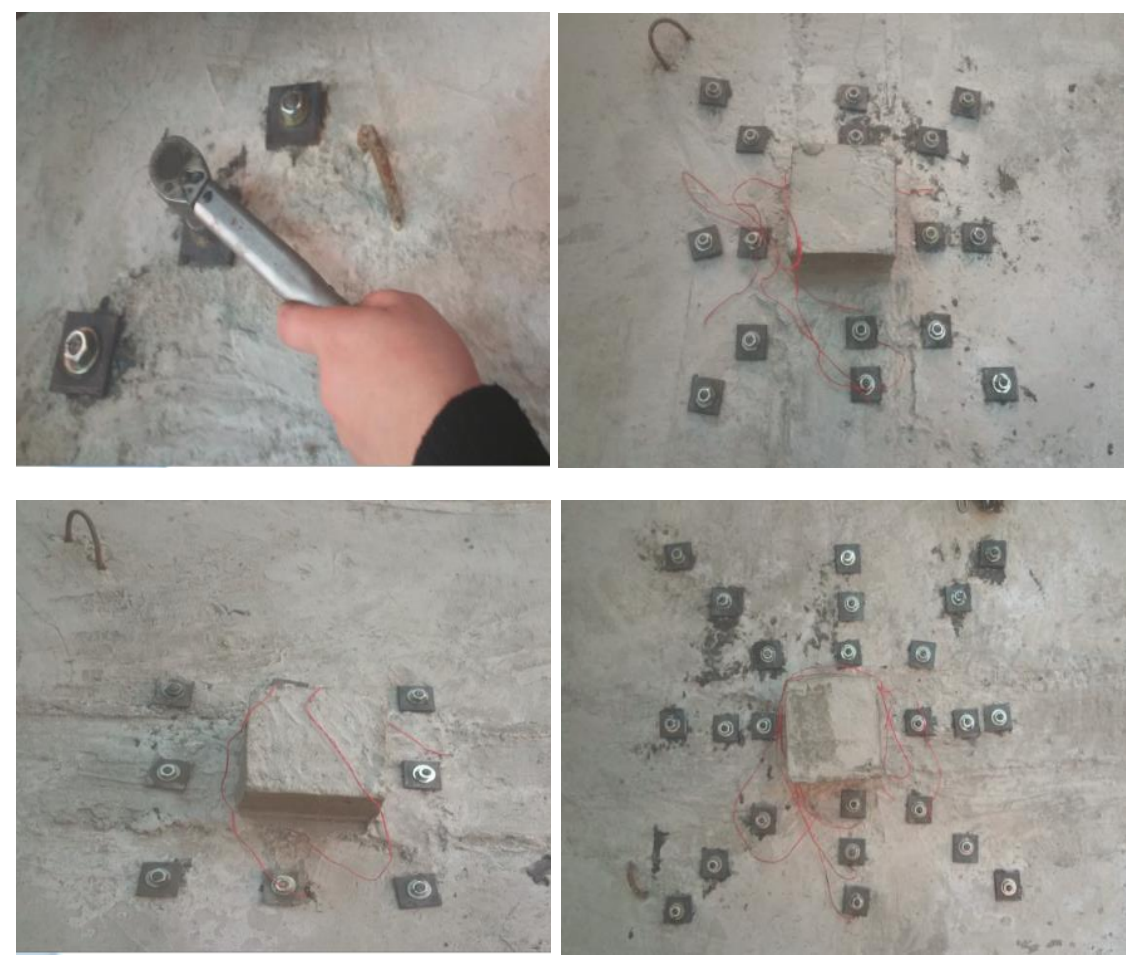

Figure 6 Tightening of bolts using the torque spanner 


\section{Testing Set-up}

A hydraulic jack of $1000 \mathrm{kN}$ capacity was used for loading the specimens. A square frame of $1000 \times 1000 \mathrm{~mm}$ was centered below the specimens as being considered simply supported. The specimens were tested horizontally below the used hydraulic jack. The applied load was increased incrementally with an increment of $50.0 \mathrm{kN}$ until the failure of specimen. The data was collected manually for each load increment $(50.0 \mathrm{kN})$.

\section{Test Results and Observations}

\subsection{Crack patterns}

Cracks for all specimens were clearly observed and followed after every loading stage at the slab's bottom surface. The propagation of cracks was followed and marked till the final mapping of the crack pattern. The evolution of cracks in all specimens follows almost a similar pattern. First, diagonal cracks spread outside the perimeter of the prestressed bolts at a load of about $150 \mathrm{kN}$. At a loading from $150 \mathrm{kN}$ to $350 \mathrm{kN}$ a tangential shear cracks grew around the column on the lines of bolts. For a loading above $350 \mathrm{kN}$ up to failure, all diagonal cracks grew wider extending to the edge of the specimens until radial cracks had been developed. Near failure stage, strain of bolts became very high according to the reading shown on strain gauge recorder but without yielding of bolts. After investigating the cracking load of enhanced slabs A1-8, A2-16 and A3-24 and comparing it to their reference slab $A_{0}$, it can be noticed that the recorded cracking load of the enhanced slabs extended to values over the failure load of their reference slab. The cracking load of the enhanced specimens in average was nearly $83.3 \%$ of their failure load, as shown in Table 4. The crack pattern of tested specimens is illustrated in Figs. 7and 8. 

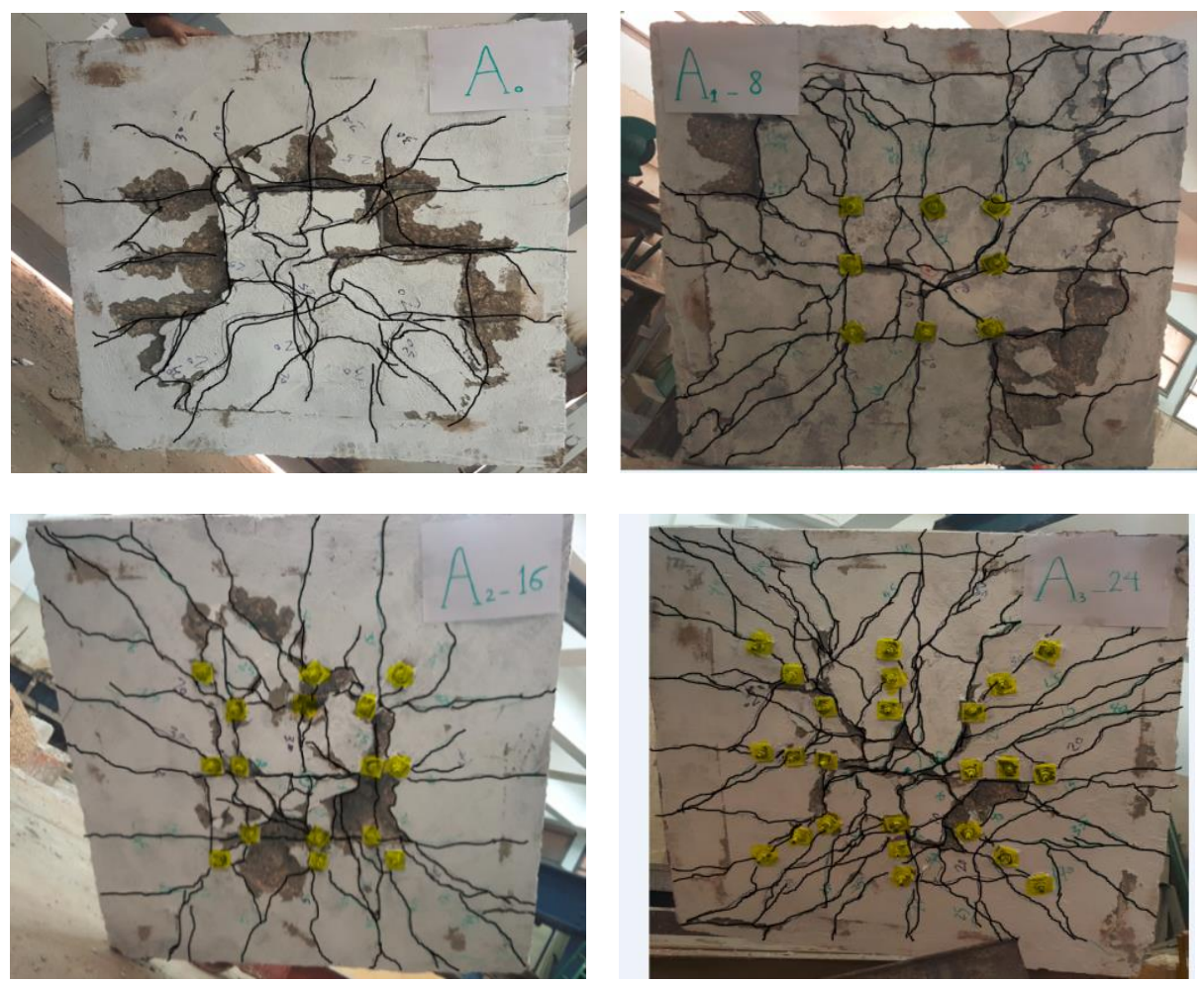

Figure 7 The crack pattern in the tension side for all tested slabs
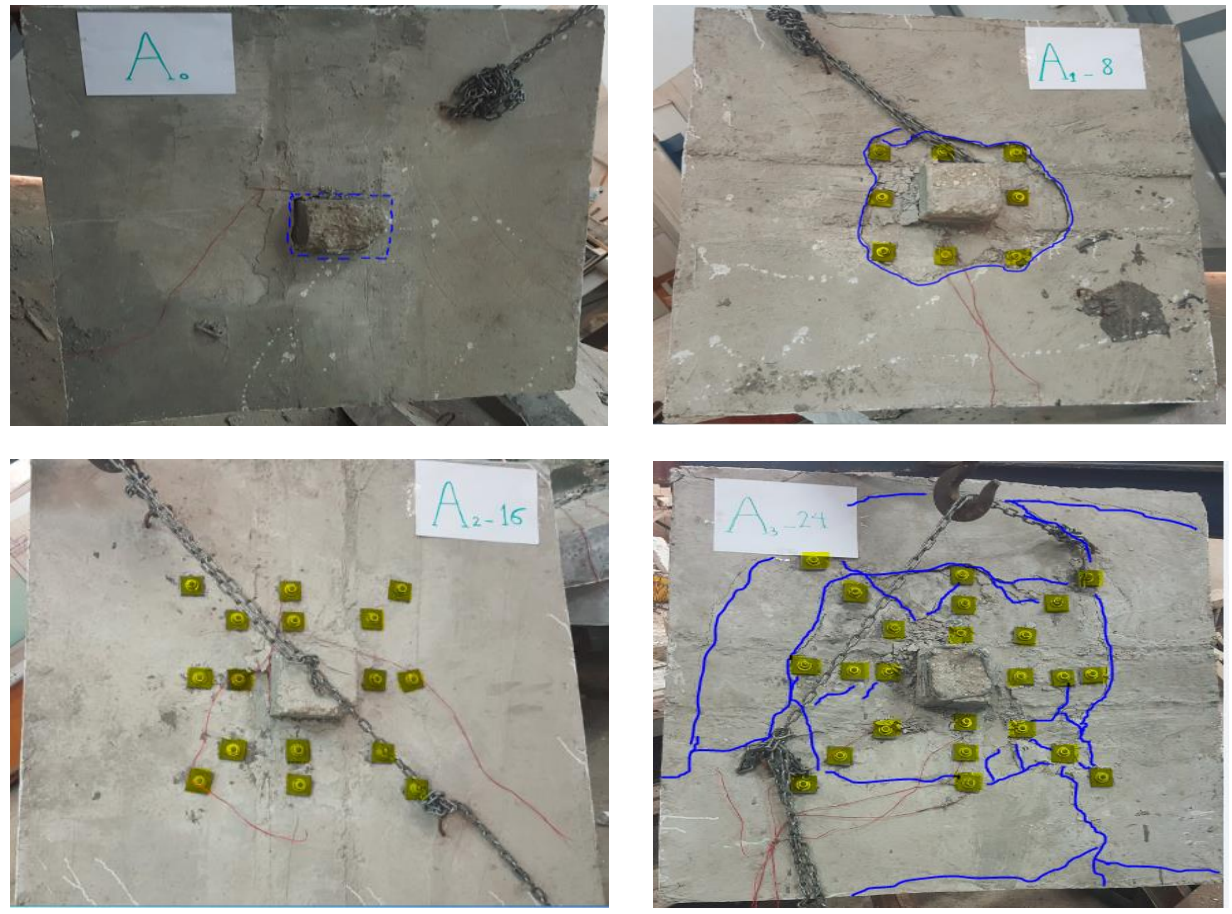

Figure 8 The crack pattern in the compression side for all tested slabs 


\subsection{Deflection Characteristics}

The load-deformation curves of the tested slabs are illustrated in Fig. 9. From these relationships, it could be noticed that the rate of deformation was lined up to the cracking load and the increasing in the applied load accompanied with increasing in cracks' propagation, the rate of deflection raised fast up to failure. Comparing the deflection of the enhanced slabs with their reference slab, it could be noticed that there was a significant enhancement in strain energy. The enhanced slab with 8-prestressed bolts A1-8 improved the deformability by about $19.8 \%$ relative to the reference slab $\left(\mathrm{A}_{\mathrm{o}}\right)$ at failure load. The enhanced slab with 16-prestressed bolts A2-16 improved the deformability by about 40.7 $\%$ relative to the reference slab at failure load. For slab with 24-prestressed bolts A3-24, the deformability had enhanced by about $46.5 \%$.

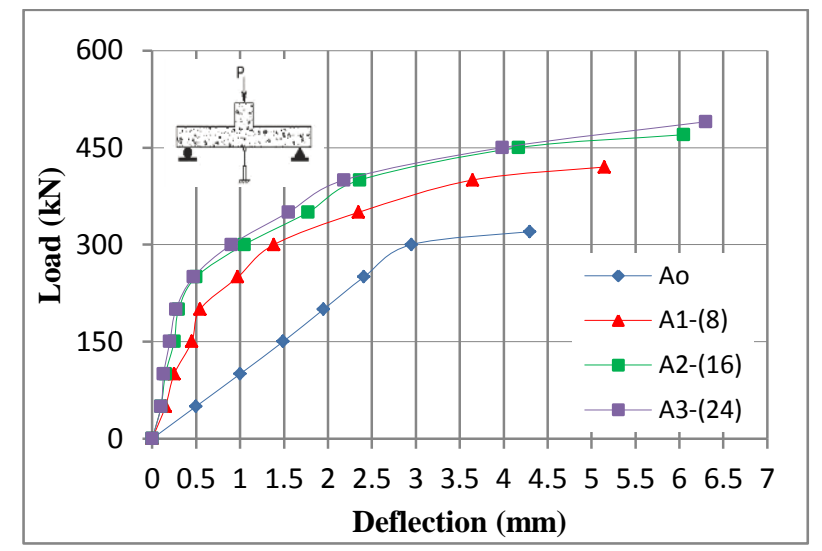

Figure 9 Load-deflection relationship of verified slabs

\subsection{Strain Characteristics}

Figure 10 presents the load-strain relationships of the tested slabs for both prestressed bolts and flexural reinforcement steel. It implies that further the cracking load period, strains in bolts significantly raised up to failure. According to Fig. 10a of specimen A1-8, the prestressed bolts reached yield point at $95 \%$ of the ultimate load, while flexural reinforcement yielded at $38 \%$ of the ultimate punching load compared with the reference slab which had a yield point for flexural reinforcement at almost $46 \%$ of ultimate punching load. This refers to the addition of the 8 prestressed bolts which delay yield. For specimen A2-16 enhanced with 16 prestressed bolts, it could be observed that the prestressed bolts of the first row reached the yield point at $74 \%$ of the ultimate punching load, while the prestressed bolts of the second row reached the yield point at almost $96 \%$. This indicated that the punching tensile strains in concrete were primarily resisted by the second row. Flexural reinforcement for this specimen reached the yield point at $32 \%$ of the ultimate punching load, as shown in Fig. 12b. For specimen A3-24 enhanced with 24 prestressed bolts, the 
prestressed bolts of the first row reached the yield point at $81 \%$ of the ultimate punching load, while for the second row they reached the yield point at $91 \%$ of the ultimate punching load. For the third row, it hadn't reached yield. The flexural reinforcement for this specimen reached yield at almost $30 \%$ of the ultimate punching load, as shown in Fig. 10d.

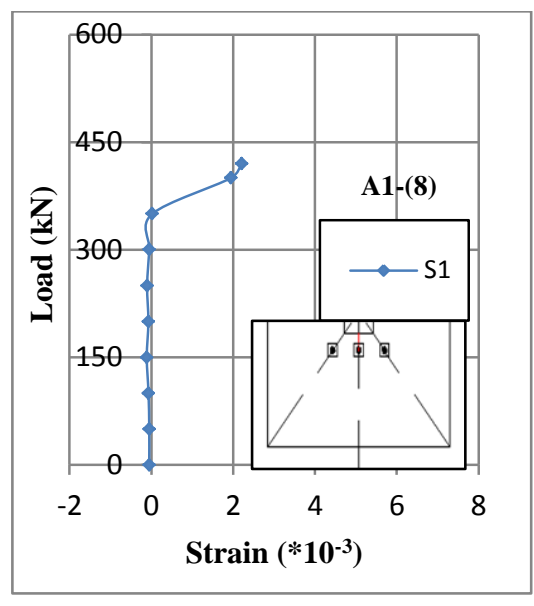

a) Specimen A1-8

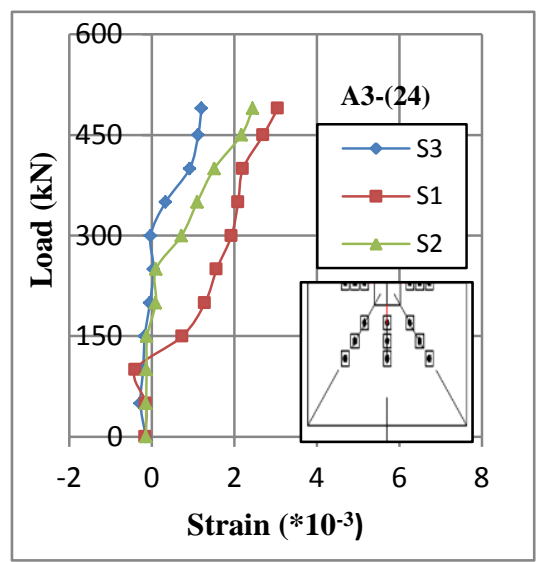

c) Specimen A3-24

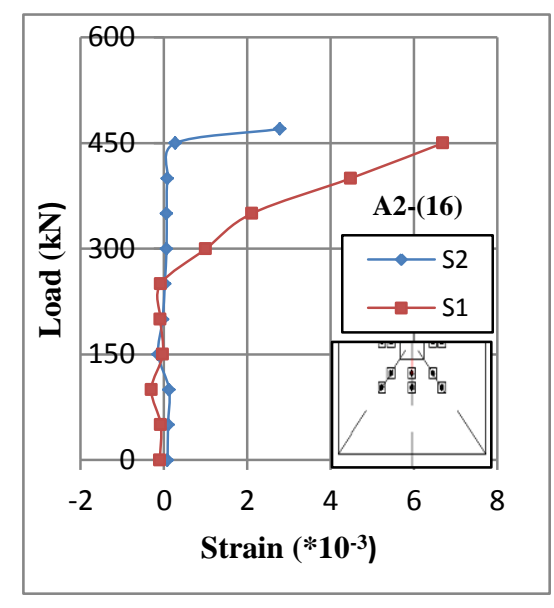

b) Specimen A2-16

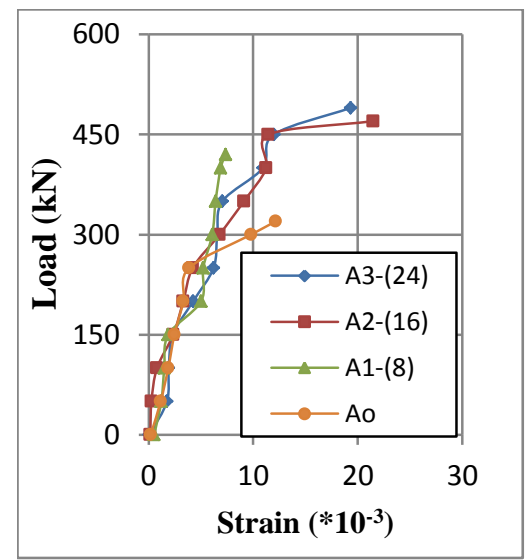

d) All specimens

Figure 10 Load-strain relationships of the enhanced specimens

\subsection{Punching Load Capacity}

Table 4 shows the verified punching failure load of the tested slabs. It could be noticed that all the enhanced slabs gained greater punching failure load values compared with the reference slab but with various ratios. For specimen A1-8 which enhanced by adding 8 prestressed bolts, the ultimate punching shear strength was $131.25 \%$ of that of the reference specimen $\mathrm{A}_{\mathrm{o}}-\mathrm{o}$. For specimen A2-16 with 16 prestressed bolts as shear reinforcement, the ultimate punching 
shear strength was $146.88 \%$ relative to the reference slab. This due to the developed number of shear prestressed bolts. While, increasing the number of prestressed bolts to 24 wasn't of such a big contribution in improving the ultimate punching shear capacity. The ultimate punching shear capacity was slightly enhanced and was $153 \%$ of the reference specimen. These results are shown in Fig. 11.

Table 5 Cracking and failure loads of the tested slabs

\begin{tabular}{|c|cc|}
\hline Specimen & Cracking load $(\mathrm{kN})$ & Failure load $(\mathrm{kN})$ \\
\hline $\mathrm{A}_{\mathrm{o}}-\mathrm{O}$ & 220 & 320 \\
$\mathrm{~A} 1-8$ & 350 & 420 \\
$\mathrm{~A} 2-16$ & 400 & 470 \\
$\mathrm{~A} 3-24$ & 420 & 490 \\
\hline
\end{tabular}

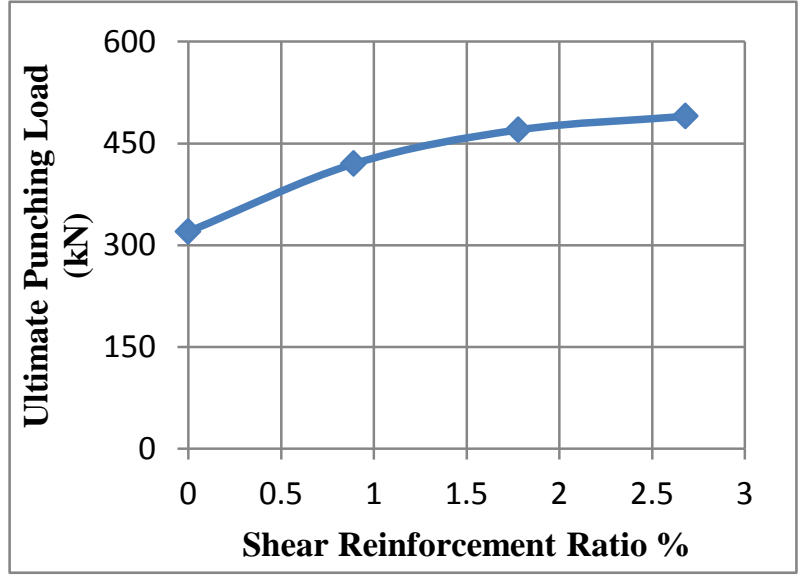

Figure 11 Influence of vertical prestressed bolts' ratios on ultimate punching shear capacity of the tested slabs

\section{Comparison between Codes Predictions and Test Results}

Table 6 Codes Predictions versus Test Results

\begin{tabular}{|c|c|c|c|c|c|}
\hline $\begin{array}{c}\mathrm{Pu}^{\text {Exp. }} \\
\mathrm{Pu}^{\text {Calc. }}\end{array}$ & $\begin{array}{c}\mathrm{ECP} \\
\mathrm{Pu}(\mathrm{kN})\end{array}$ & $\begin{array}{c}\mathrm{ACI} \\
\mathrm{Pu}(\mathrm{kN})\end{array}$ & $\begin{array}{c}\mathrm{NZS} \\
\mathrm{Pu}(\mathrm{kN})\end{array}$ & $\begin{array}{c}\mathrm{EC}-2 \\
\mathrm{Pu}(\mathrm{kN})\end{array}$ & $\begin{array}{c}\mathrm{CSA} \\
\mathrm{Pu}(\mathrm{kN})\end{array}$ \\
\hline $\mathrm{A}_{\mathrm{o}}-\mathrm{O}$ & 1.34 & 2 & 1.2 & 1.07 & 1.07 \\
\hline $\mathrm{A} 1-8$ & 1.75 & 1.16 & 1.16 & .9 & 1.48 \\
\hline $\mathrm{A} 2-16$ & 1.96 & 1.01 & 1.01 & .96 & 1.23 \\
\hline $\mathrm{A} 3-24$ & 2.05 & 1.06 & 1.06 & 1 & 1.29 \\
\hline Mean & 1.78 & 1.31 & 1.31 & 0.98 & 1.27 \\
\hline
\end{tabular}




\section{Conclusions}

Upon discussing the output results of the conducted experimental program, conclusions can be presented as follows:

1. Using the vertical prestressed bolts as shear reinforcement has a significant influence on improving crack behavior, the strain energy and punching shear capacity

2. Raising the shear reinforcement ratio has an essential effect on raising the punching shear capacity but to some extent till 16 prestressed bolts.

3. Enhancing slabs with 24 prestressed bolts significantly improves the deformability and not the punching shear capacity.

4. The ECP code is conservative for calculating the punching shear capacities ; it gives over-estimated values compared to the other codes.

\section{REFERENCES}

1- Daniel Heinzmann, Stephan Etter, Sebastian Villiger, and Thomas Taeger, "Punching tests on reinforced concrete slabs with and without shear reinforcements", ACI Struct. J. 109 (6) (2012) 787-794.

2- Stefan Lips, Miguel Fernandez Ruiz, Aurelio Muttoni, Experimental investigation on punching strength and deformation capacity of shear reinforced slabs, ACI Struct. J. 109 (6) (2012) 889-900.

3- Miguel Fernandez Ruiz, Aurelio Muttoni, Jakub Kunz, Strengthening of flat slabs against punching shear using post- installed shear reinforcement, ACI Struct. J.107 (4) (2010) 434-442.

4- Khaled Soudki, Ahmed K. El-Sayed, Tim Vanzwol, Strengthening of concrete slab-column connections using CFRP strips, king saud university. J -Engineering Science (2012) 24, 2533.

5- Ebead, U., Marzouk, H., 2002. Strengthening of two-way slabs using steel plates. ACI Structural Journal 99 (1), 23-31.

6- Harajli, M.H., Soudki, K.A., 2003. Shear strengthening of interior slabcolumn connections using fiber reinforced polymer sheets. Journal of Composites for Construction, ASCE 7 (2), 145-153.

7- A.E.M.S. Ahmed, S.E. El-Metwally, H.H. Askar, M. El-Zareef, Effect of mid-thickness rebar mesh on the behavior and punching shear strength of interior slab-column connection, HBRC J., 2015.

8- Jurgen Einpaul, Jan Bujnak, Miguel Fernandez Ruiz, and Aurelio Muttoni, Study on influence of Column Size and Slab Slenderness on punching Strength, ACI Struct. J,V. 113, No. 1, January-February 2016. 
9- A. Ghali, M.A. Sargious, A. Huizer, Vertical prestressing of flat plates around column, shear in reinforced concrete, Special Publication SP 42, ACI J. 2 (1974) 905-920.

10-Inacio Duarte, Antonio M.P. Ramos, Valter J.G. Lucio, Strengthening of flat slabs with transverse reinforcement, Challenges Civ. Construct. J. (2008) 1-7.

11-H. Mostafaei, F.J. Vecchio, P. Gauvreau, M. Semelawy, Punching shear behavior of externally prestressed concrete slabs, ASCE J. (2011) 100108.

12-A. Abdullah, C.G. Bailey, Z.J. Wu, Tests investigating the punching shear of a column-slab connection strengthened with non-prestressed or prestressed FRP plates, Construct. Build, Mater, J. (2013) 1134-1144.

13-Hamed.S Askar, Usage of prestressed vertical bolts for retrofitting flat slabs damaged due to punching shear, Alexandria Engineering Journal (2015) 54, 509518.

14-ACI committee 318, Building Code Requirements for Structural Concrete, ACI 318-11, and Commentary. American Concrete Institute, Formington Hills MI, 2011, p. 503.

15-Eurocode 2: Design of Concrete Structures - Part 1-6: General Rules and Rules for Buildings, European prestandard. European Committee for Standardization, 2004, p. 253.

16-CSA A23.3-04: Design of concrete structures, Canadian Standards Association, Rexdale, Ontario, 2004.

17-NZS 3101.part 1: Concrete structures standard, New Zealand standard, 2006.

18-Egyptian code committee 203: Egyptian code of practice for design and construction of reinforced concrete structures, housing and building research center, Cairo, 2018. 